\title{
Priority setting for conservation in south-west Cameroon based on large mammal surveys
}

\author{
P.F. Forboseh, M. Eno-Nku and T.C.H. Sunderland
}

\begin{abstract}
The forests of the Cameroon-Nigeria transboundary region have been highlighted as a high conservation priority, yet many of the extant forest remnants remain relatively unknown, particularly with regard to the occurrence of large mammals. Between 2002 and 2004 we surveyed the large mammal fauna of the Mone and Ejagham Forest Reserves and the Upper Banyang, Nkwende Hills and Etinde forests of southwest Cameroon. Our objective was to document the extant large mammal species as an important step in the review of government priorities to identify key sites within the region for conservation and management. We reviewed the available literature on mammal distribution and then surveyed the forests for mammal and human signs. Despite a growing illegal commercial
\end{abstract}

trade in wildlife, particularly for bushmeat, many sites retain populations of one or more threatened and locally rare large mammal species of significant conservation importance. Moreover, the sites collectively complement each other in terms of their representation of the threatened large mammal fauna. An emphasis on the enforcement of wildlife legislation and minimizing logging impact are of primary importance for the conservation of large mammals in these and other forest remnants in south-west Cameroon. In addition, at some sites, there already exists community interest in active wildlife management.

Keywords Cameroon, forest, land use planning, large mammals, Nigeria, priority setting.

\section{Introduction}

The Lower Guinean forests of the Cameroon-Nigeria transboundary area collectively constitute a regional conservation priority (Oates et al., 2004) because of their high levels of biodiversity and the high degree of threat (Myers et al., 2000). Threatened species in the area include the Critically Endangered Cross River gorilla Gorilla gorilla diehli, the Endangered Nigeria-Cameroon chimpanzee Pan troglodytes vellerosus, the Endangered drill Mandrillus leucophaeus and the Endangered Preuss's guenon Cercopithecus preussi (IUCN, 2006). The region also contains many restricted range bird species

P.F. Forboseh ${ }^{1}$ (Corresponding author) and T.C.H. Sunderland ${ }^{2}$ Wildlife Conservation Society, PO Box 437, Limbe, Cameroon.

E-mail forboseh@yahoo.com

M. Eno-Nku ${ }^{3}$ WCS - Cameroon-Nigeria Transboundary Project, PO Box 1308, Limbe, Cameroon.

'Current address: Plan Cameroon, PO Box 25236, Messa, Yaoundé, Cameroon.

${ }^{2}$ Current address: Centre for International Forestry Research, PO Box 6596 JKPWB, Jakarta, Indonesia.

${ }^{3}$ Current address: WWF Coastal Forest Programme, PO Box 1169, Limbe, Cameroon.

Received 23 May 2005. Revision requested 21 September 2005 Accepted 24 April 2006
(BirdLife International, 2000) and endemic plants (Cable \& Cheek, 1998; Cheek et al., 2000).

The large mammals of some areas of south-west Cameroon, identified by the Government's 2002 land use planning process (Plan de Zonage) as having critically important biodiversity values, are relatively unknown. Here we document the extant large mammal fauna of five sites in this area: the Ejagham and Mone Forest Reserves and the Etinde, Nkwende Hills and Upper Banyang forests. The first two sites are Forest Reserves established during the colonial era for timber production and, as such, have no formal protection. However, the Plan de Zonage recommends that Ejagham Forst Reserve be integrated into the surrounding Korup National Park, and that the Mone Forest Reserve be upgraded to a Wildlife Sanctuary. Although the Etinde, Nkwende Hills and Upper Banyang forests are currently without any formal classification, the first two have been included as potential protected areas in the Plan de Zonage, and the latter is part of a logging concession currently allocated to the Dutch company Wijma. The Etinde forest has been separately recommended for gazettement as an Ecological Reserve (MINEF, 2001). Large mammal surveys were undertaken in the Etinde and Nkwende Hills forests to determine their conservation value in comparison with other sites in the region, and in the Upper Banyang forest because data on 
large mammal abundance and distribution is crucial in the long-term management of the concession to mitigate the impacts of commercial logging. Here we highlight the conservation importance of each of these five forests and discuss options for their conservation.

\section{Study area}

The Cameroon-Nigeria transboundary region extends from Cross River in Nigeria to the River Sanaga in Cameroon (Fig. 1). The area spans an altitudinal range from sea level to 4,095 $\mathrm{m}$ on Mount Cameroon, the highest peak in West Africa and part of a mountain chain that extends northwest-southeast into the Gulf of Guinea. Although there is local climatic variation, the region generally has two seasons: a dry season in
November-February and a wet season March-October. Annual rainfall is $2,000-3,500 \mathrm{~mm}$ but can exceed 10,000 $\mathrm{mm}$ in Debundscha, south-west of Mount Cameroon. The heaviest rain falls during July-September (Oates et al., 2004). Temperatures are relatively constant with monthly mean minima and maxima, respectively, of $22-24^{\circ} \mathrm{C}$ and $24-32^{\circ} \mathrm{C}$ (Fraser et al., 1998). The vegetation at low altitudes comprises a coastal area of mangroves and inland dense humid evergreen GuineanCongolian forest of the Atlantic Biafran type, which is dominated by the plant families Caesalpinaceae, Euphorbiaceae, Olacaceae and Sterculiaceae (Letouzey, 1968). At higher altitudes there are submontane and montane forest zones (Cable \& Cheek, 1998; Cheek et al., 2000). The forests of the region are well-drained by a network of rivers that form part of the Cross River basin.

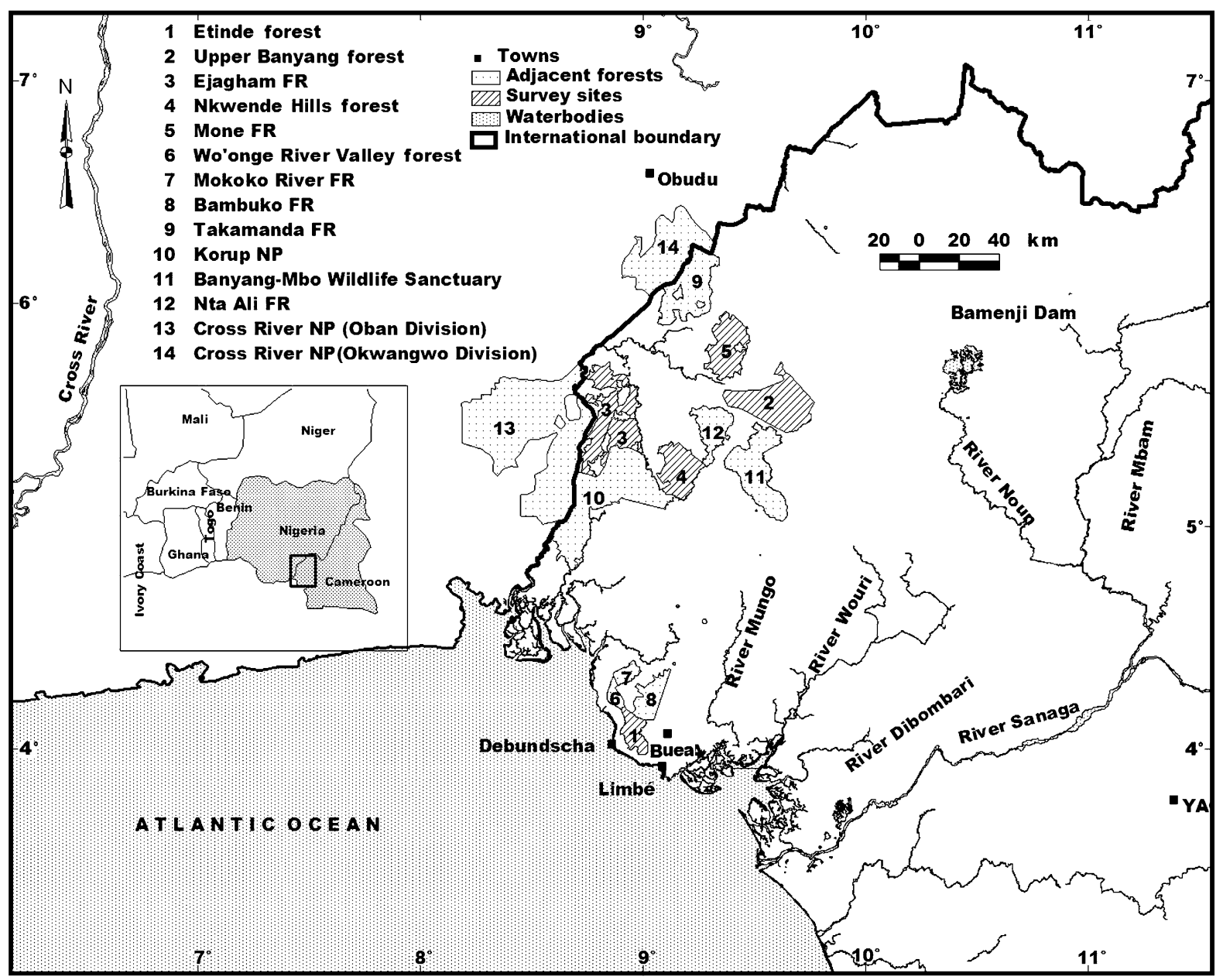

Fig. 1 Location of the survey sites (1-5) and of protected areas and forest reserves in south-west Cameroon and in the Cameroon-Nigeria transboundary area. The inset shows the location of the main map in West Africa. FR, Forest Reserve; NP, National Park. 


\section{Methods}

Before carrying out the surveys we reviewed the available literature to determine which species of large mammal had previously been recorded in each of the five forests (Sanderson, 1940; Struhsaker, 1967; Bowden, 1986; Gadsby \& Jenkins, 1992; Usongo, 1996, 1997; Ekobo, 2003). Mammal nomenclature follows Kingdon (1997). We used reconnaissance walks (recces) to collect data on animal signs, including dung, nests and feeding signs, and human signs (hunting trails, huts, village footpaths, gunshots, cartridges and snares). All recces ran perpendicular to existing footpaths and were placed at least $5 \mathrm{~km}$ apart. The cutting of recces and recording of habitat types and animal signs followed the procedures of White \& Edwards (2000). The field team comprised a principal observer, a second observer, and local hunters with considerable experience in the identification of mammal signs. We recorded more ape nests than other signs, and therefore for ape nests only we used the $\chi^{2}$ goodness-of-fit test to determine whether they were randomly distributed amongst sites. Following Dupain et al. (2004), we calculated expected values as $\mathrm{E}\left\{\mathrm{w}_{j}\right\}=x_{j} y$, where $x_{j}$ is the proportional extent of site $j, y$ is the total number of nests in all sites, and $\mathrm{E}\left\{\mathrm{w}_{j}\right\}$ is the expected number of nests in site $j$. Table 1 summarizes the distribution of sample effort across sites and habitat types.

\section{Results}

Of the 25 large mammal species recorded from the area we observed signs of 17 , but not all species at every site.
We observed signs of the drill, the putty-nosed monkey Cercopithecus nictitans and the mona monkey Cercopithecus mona at all five sites (Table 2). There were signs of the red-eared monkey Cercopithecus erythrotis in the Mone Forest Reserve, Nkwende Hills and Etinde forests, but not the Ejagham Forest Reserve and Upper Banyang forest, and our only record of the Cross River gorilla came from the Mone Forest Reserve where we heard one vocalization and observed a recent nest (of mostly green vegetation). Although we found other fresh and old tree nests in the Mone and Ejagham Forest Reserves and Nkwende Hills and Etinde forests, examination of each nest site for hair, dung or other signs indicated they were all unequivocally chimpanzee nests. Our only records of the red-cap mangabey Cercocebos torquatus and the crowned guenon monkey Cercopithecus pogonias were in the Nkwende Hills and Etinde forests, respectively. We found signs of forest elephants Loxodonta africana cyclotis and duikers Cephalophus spp. at all sites, except that we found no signs of elephants and the yellow-backed duiker Cephalophus silvicultor in the Etinde forest. Our single record of the forest buffalo Syncerus caffer nanus was in the Nkwende Hills forest.

Encounter rates for all large mammal and human signs during the reccee walks are given in Table 3 . We encountered more ape nests $\left(1.22\right.$ nest groups $\left.\mathrm{km}^{-1}\right)$ in Etinde forest than at other sites $\left(0.17\right.$ nest groups $\mathrm{km}^{-1}$ or less), and the distribution of nests was significantly different among the four sites where we found nests $\left(\chi^{2}=89.804, \mathrm{df}=3, \mathrm{P}<0.0001\right)$. We recorded more elephant signs in the Ejagham Forest Reserve (0.68 signs $\mathrm{km}^{-1}$ ) than in other sites ( 0.23 signs $\mathrm{km}^{-1}$ or less). We

Table 1 Details of surveys in each of the five forest sites (Fig. 1), with their total area, and the \% of seven major habitat types (of the total forest area) encountered during the recce walks.

\begin{tabular}{|c|c|c|c|c|c|}
\hline & $\begin{array}{l}\text { Mone Forest } \\
\text { Reserve }\end{array}$ & $\begin{array}{l}\text { Ejagham Forest } \\
\text { Reserve }\end{array}$ & $\begin{array}{l}\text { Upper Banyang } \\
\text { forest }\end{array}$ & $\begin{array}{l}\text { Nkwende Hills } \\
\text { forest }\end{array}$ & Etinde forest \\
\hline \multicolumn{6}{|l|}{ Survey details } \\
\hline Dates & Apr.-May 2004 & Jan.-Feb. 2003 & Feb. 2004 & Oct.-Nov. 2002 & Sep. 2004 \\
\hline No. of recces & 14 & 9 & 12 & 15 & 5 \\
\hline Recce length (km) & 2.500 & 2.500 & 2.500 & 2.500 & 2.000 \\
\hline Total recce length $(\mathrm{km})$ & 35.000 & $22.100^{1}$ & $28.075^{2}$ & $36.150^{3}$ & $9.000^{4}$ \\
\hline Area $\left(\mathrm{km}^{2}\right)$ & 538 & 749 & 650 & 800 & 310 \\
\hline \multicolumn{6}{|l|}{ Habitat types (\%) } \\
\hline Primary forest & 86.3 & 87.8 & 75.9 & 80.5 & 72.2 \\
\hline Secondary forest & 6.9 & 0.5 & 5.3 & 10.5 & 15.6 \\
\hline Liana dominated forest & 6.6 & 9.0 & 15.0 & 2.8 & 0.0 \\
\hline Marsh & 0.0 & 2.7 & 1.4 & 5.5 & 0.0 \\
\hline Farmland & 0.0 & 0.0 & 2.8 & 0.6 & 3.3 \\
\hline Clearing & 0.3 & 0.0 & 0.0 & 0.0 & 0.0 \\
\hline Transition & 0.0 & 0.0 & 0.0 & 0.0 & 8.9 \\
\hline
\end{tabular}

${ }^{1}$ One recce was $2.100 \mathrm{~km}$ long

${ }^{2}$ Three recces were each $2.050,1.700$ and $1.825 \mathrm{~km}$ long

${ }^{3}$ One recce was $1.150 \mathrm{~km}$ long

${ }^{4}$ One recce was $1.000 \mathrm{~km}$ long 
P. F. Forboseh et al.

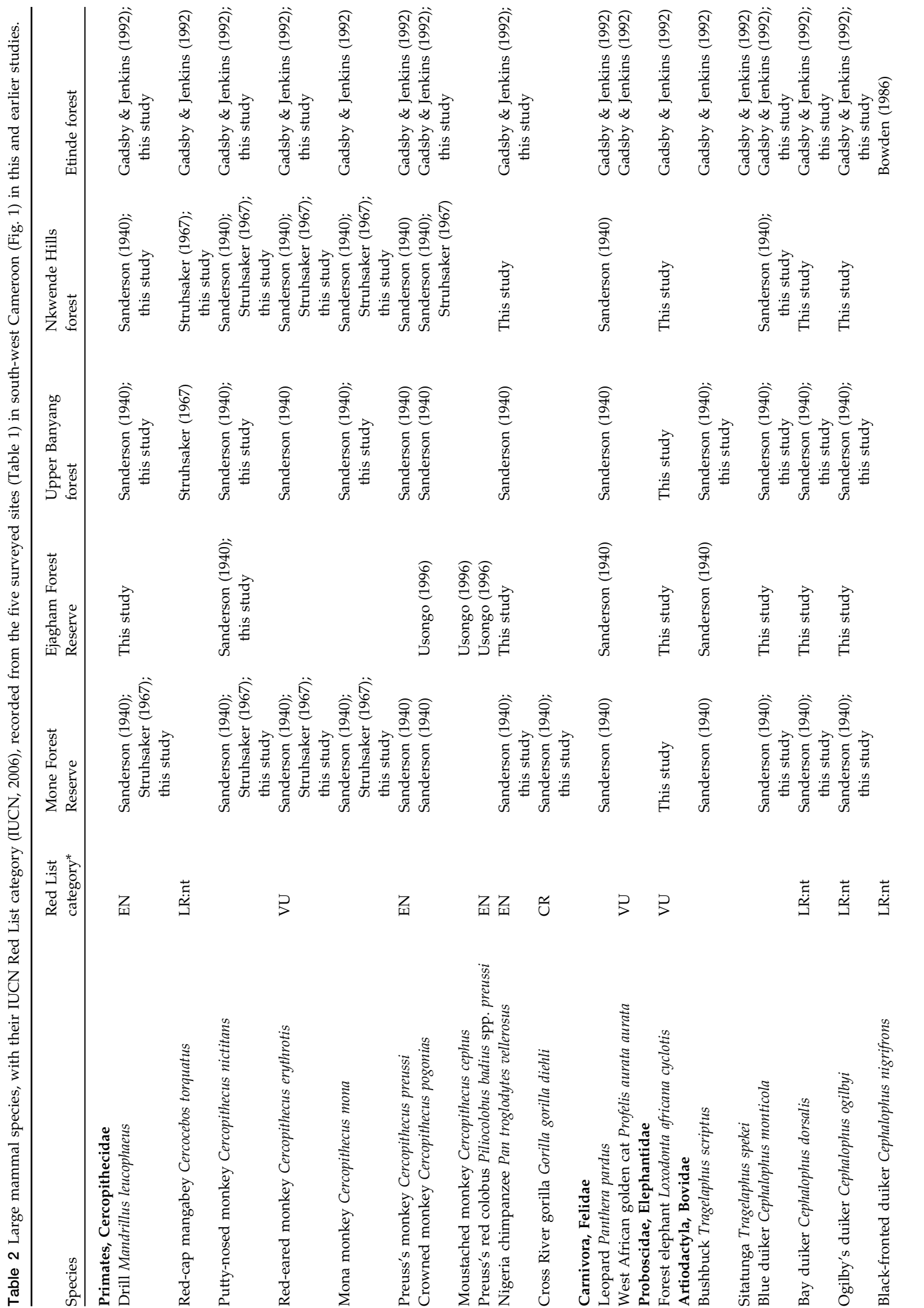




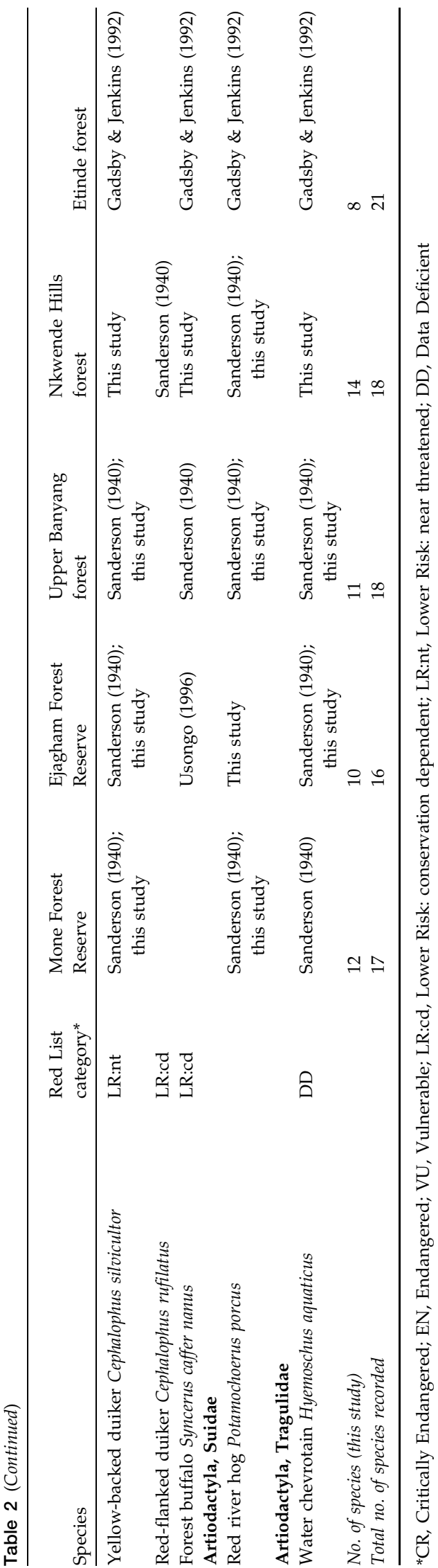

observed more red duiker (i.e. bay duiker Cephalophus dorsalis and Ogilby's duiker Cephalophus ogilbyi) signs in the Upper Banyang forest (2.42 signs $\mathrm{km}^{-1}$ ) and in the Mone Forest Reserve (1.72 signs $\mathrm{km}^{-1}$ ) than elsewhere (1.13 signs $\mathrm{km}^{-1}$ or less). We encountered many human signs, including hunting trails, huts and village footpaths, but gunshots, cartridges and snares were less common. Exceptions include the Etinde forest with 1.89 cable snares $\mathrm{km}^{-1}$ compared to $<0.5$ cable snares $\mathrm{km}^{-1}$ elsewhere, and the Nkwende Hills forest and the Ejagham Forest Reserve with 0.25 cartridges $\mathrm{km}^{-1}$ compared to $<0.11$ cartridges $\mathrm{km}^{-1}$ at the other sites.

\section{Discussion}

The Mone and Takamanda Forest Reserves would be expected to have a similar large mammal fauna because of their proximity (Fig. 1). Sunderland-Groves \& Maisels (2003) list 16 large mammal species for the Takamanda Forest Reserve, including those that we recorded in Mone Forest Reserve and four others recorded by Groves (2002). Similarly, the Ejagham Forest Reserve, where we recorded the previously unreported forest elephant, probably has a faunal diversity similar to the contiguous Korup National Park and Cross River National Park in Nigeria (Gartlan, 1989). Dunn \& Okon (2003) and Usongo (1997) collectively reported 14 large mammal species for Korup, including eight that we recorded in the Ejagham Forest Reserve. The Upper Banyang forest, for which we were unable to locate any previous reports of large mammal surveys, would be expected to have a faunal diversity similar to the neighbouring Banyang-Mbo Wildlife Sanctuary, and we recorded four of the seven large mammal species included in the legal instrument that establishes Banyang-Mbo as a Wildlife Sanctuary (Bechem \& Nchanji, 2001; Nchanji, 2003), including the forest elephant and drill. Similarly the Nkwende Hills forest does not appear to have been previously surveyed; it effectively forms a corridor linking Ejagham Forest Reserve, Korup National Park and Nta Ali Forest Reserve, and would be expected to have a faunal diversity similar to these adjoining sites. Despite the many factors, both natural and human-induced, which restrict habitat utilization and movement of the Mount Cameroon fauna, the Etinde forest and the adjoining Wo'onge River Valley forest and Bambuko and Mokoko River Forest Reserves are likely to have a similar large mammal fauna. Gadsby \& Jenkins (1992) list mammal species found in the Mokoko River Forest Reserve and the Etinde and Wo'onge Valley forests, and Ekobo (2003) reports the red-cap managabey, forest elephant and bushbuck Tragelaphus scriptus in the Bambuko Forest Reserve. 
Table 3 Encounter rates $\left(\mathrm{km}^{-1}\right)$ of large mammal (Table 2) and human signs in the five surveyed forest reserves (Table 1) in south-west Cameroon (Fig. 1).

\begin{tabular}{|c|c|c|c|c|c|}
\hline & $\begin{array}{l}\text { Mone Forest } \\
\text { Reserve }\end{array}$ & $\begin{array}{l}\text { Ejagham Forest } \\
\text { Reserve }\end{array}$ & $\begin{array}{l}\text { Upper Banyang } \\
\text { forest }\end{array}$ & $\begin{array}{l}\text { Nkwende Hills } \\
\text { forest }\end{array}$ & Etinde forest \\
\hline \multicolumn{6}{|l|}{ Sightings $^{1}$} \\
\hline C. pogonias & & & & & $0.78,0.14,7.0$ \\
\hline C. nictitans & $0.23,0.03,8.0$ & & $0.04,0.04 .1 .0$ & $0.03,0.03,1.0$ & \\
\hline C. erythrotis & & & & $0.03,0.03,1.0$ & \\
\hline C. mona & $0.14,0.03,5.0$ & & $0.04,0.04,1.0$ & & \\
\hline C. monticola & 0.06 & & 0.04 & & \\
\hline Red duikers (C. dorsalis, C. ogilbyi) & 0.06 & 0.05 & 0.04 & & \\
\hline H. aquaticus & & 0.05 & & & \\
\hline T. scriptus & & & 0.04 & & \\
\hline \multicolumn{6}{|l|}{ Nests $^{1}$} \\
\hline G. gorilla & $0.03,0.03,1.0$ & & & & \\
\hline P. troglodytes & $1.37,0.14,9.6$ & $0.14,0.05,3.0$ & & $0.72,0.17,4.3$ & $3.9,1.22,3.2$ \\
\hline \multicolumn{6}{|l|}{ Dung } \\
\hline L. africana cyclotis & 0.17 & 0.36 & 0.21 & 0.14 & \\
\hline P. porcus & 0.09 & 0.45 & 0.21 & & \\
\hline C. silvicultor & 0.03 & 0.09 & 0.14 & 0.03 & \\
\hline Red duikers & 0.06 & 1.31 & 2.14 & 0.19 & \\
\hline C. monticola & 0.06 & 1.14 & 1.14 & 0.17 & \\
\hline H. aquaticus & & 0.05 & & 0.03 & \\
\hline \multicolumn{6}{|l|}{ Vocalization } \\
\hline G. gorilla & 0.03 & & & & \\
\hline P. troglodytes & & & & & 0.22 \\
\hline C. nictitans & 0.17 & 0.23 & 0.04 & 0.17 & 0.11 \\
\hline C. pogonias & & & & & 0.33 \\
\hline C. torquatus & & & & 0.06 & 0.33 \\
\hline C. mona & 0.06 & & 0.11 & 0.03 & \\
\hline C. erythrotis & 0.06 & & & & \\
\hline \multicolumn{6}{|l|}{ Feeding } \\
\hline M. leucopheus & 0.03 & & 0.14 & & 0.11 \\
\hline P. porcus & 0.34 & & 1.28 & 0.47 & \\
\hline L. africana cyclotis & 0.06 & & & & \\
\hline \multicolumn{6}{|l|}{ Tracks } \\
\hline M. leucopheus & & 0.09 & & 0.03 & \\
\hline H. aquaticus & & 0.27 & 0.04 & 0.03 & \\
\hline P. porcus & 0.46 & 0.72 & 0.14 & & \\
\hline S. caffer & & & & 0.03 & \\
\hline \multicolumn{6}{|l|}{ Human signs } \\
\hline Gunshots & 0.03 & 0.05 & & 0.06 & \\
\hline Cartridges & & 0.23 & 0.11 & 0.25 & 0.11 \\
\hline Snares & 0.49 & 0.41 & 0.41 & 0.47 & 1.89 \\
\hline Others $^{2}$ & 1.60 & 2.62 & 4.22 & 2.43 & 2.11 \\
\hline
\end{tabular}

${ }^{1}$ Where the data is available the encounter rates are given as individual, group, mean

${ }^{2}$ Roads, old village sites, machete cuts or broken stems resulting from a single passage, human trails, honey extraction, hunter's huts, fireplaces, bark stripping, nut cracking sites, tree cutting/ timber extraction/ canoe construction

Cameroon provides national protection for animals, including mammals, under Law No. 94/01 of 20 January 1994 relating to Forestry, Wildlife and Fisheries Management, and Decree No. 95/466/PM of 20 July 1995 that lays down the terms and conditions for implementing the Law. The Red List (IUCN, 2006) largely informs national protection. Article 78(2) of the law forbids the hunting and capture of totally protected species. Article 101 incriminates anybody found in possession of parts or the whole body of a totally protected animal, and Article 158 specifies the penalty for infractions that include a fine of USD 6,000-20,000 and imprisonment for 1-3 years. In addition, traditional and religious beliefs that prohibit the killing of some species may provide local protection at some sites; local taboos prohibit the consumption of chimpanzees and, until recently, afforded the species a high level of protection on most of Mount Cameroon. Cameroon has also signed and ratified the Convention on Biological Diversity and CITES. However, a growing interest in 
commercial wildlife hunting and logging, and the weak enforcement of wildlife legislation, threatens wildlife populations in the region. Waltert et al. (2002) provided evidence of a declining primate population in the Korup National Park that they attributed to logging and illegal hunting for the supply of bushmeat to urban areas, including Yaoundé (Edderai \& Dame, 2006).

Despite the threats to wildlife in the region the five sites surveyed still hold important populations of large mammals. Even the relatively small, but inaccessible, Etinde forest, which lies near the large towns of Limbe and Buea, retains important populations of chimpanzees and other primates, with a chimpanzee encounter rate higher than the 0.54 and 0.22 nest groups $\mathrm{km}^{-1}$ recorded for Takamanda Forest Reserve and Mbulu forest, respectively (Groves, 2002). The Ejagham Forest Reserve is the most important of the five study sites for forest elephants, and the encounter rate there is higher than or comparable to the 0.26 signs $\mathrm{km}^{-1}$ in Korup National Park (Usongo, 1997) and 0.77 signs km ${ }^{-1}$ in the adjacent Cross River National Park (Dickinson, 1995). We recorded encounter rates of red duiker signs in the Upper Banyang forest and Mone Forest Reserve that greatly exceed rates in Korup National Park (1.08 signs $\mathrm{km}^{-1}$ for all Cephalophus spp. except blue duikers; Usongo, 1997).

At each of the five sites one or more Endangered or Vulnerable species (IUCN, 2006) were recorded. These include the Nigeria-Cameroon chimpanzee, drill, redeared monkey, and possibly Preuss's monkey, all endemic to the Cameroon-Nigeria transboundary region, and indicate that each of the five sites is a high conservation priority. This is further augmented by the fact that each site is of conservation value for different species. Etinde forest, for example, is an important refuge for chimpanzees. Similarly, the relatively high abundance of forest elephants in the Ejagham Forest Reserve and of locally rare red duikers in the Upper Banyang forest suggest the need for further protection of these areas. The presence of the Cross River gorilla in the Mone Forest Reserve provides support for upgrading it to a Wildlife Sanctuary, as recommended by the Plan de Zonage.

This research highlights the conservation priorities for large mammals in the region and concurs with the findings of the Government's Plan de Zonage that these forests are of important conservation value. The implementation of the recommendations of the Plan de Zonage for the Ejagham and the Mone Forest Reserves and the Nkwende Hills forest will be critical. In addition, there is an initiative, being led by the Government of Cameroon and WWF with funding from the German Development Bank, to include Etinde forest in a wider Mount Cameroon National Park. Providing data on mammal distribution in the Upper Banyang logging concession has enabled Wijma to limit the impact of commercial logging in areas where populations of large mammals are present.

An emphasis on the enforcement of wildlife legislation and minimizing logging impact are of primary importance for the conservation of large mammals in these and other forest remnants in south-west Cameroon. In addition, at some sites, there already exists community interest in active wildlife management. For example, since 1998 the Mokoko Wildlife Management Association has been fixing annual hunting quotas and monitoring wildlife offtake from the Mokoko River Forest Reserve adjacent to Etinde forest (Ntube et al., 2002). This Management Association potentially provides a model that could be emulated at other sites in the region, although the impact that the Association is having on the conservation of the large mammal population of the area needs further evaluation.

\section{Acknowledgements}

The Cameroon-Nigeria Transboundary Project is an initiative of the Wildlife Conservation Society, USA, working with the Ministry of Forestry and Wildlife of Cameroon. We are grateful to Drs Fiona Maisels, Anthony Nchanji, John Oates, and Roger Fotso for their comments on an earlier draft of this paper. The field work was funded from a grant from the MacArthur Foundation whose support for conservation-based research and capacity building in the region has been considerable.

\section{References}

Bechem, M.E. \& Nchanji, A.C. (2001) Large Mammals of the Banya-Mbo Wildlife Sanctuary. Unpublished Report, Wildlife Conservation Society Banyang-Mbo Wildlife Sanctuary Project, Nguti, Cameroon.

BirdLife International (2000) Threatened Birds of the World. Lynx Edicions, Barcelona, Spain and BirdLife International, Cambridge, UK.

Bowden, C.G.R. (1986) Records of other species of mammals from western Cameroon. In Conservation of Cameroon Montane Forests (ed. S.N. Stuart), pp. 201-203. International Council for Bird Preservation, Cambridge, UK.

Cable, S. \& Cheek, M. (1998) The Plants of Mount Cameroon: A Conservation Checklist. Royal Botanic Gardens, Kew, UK.

Cheek, M., Mackinder, B., Gosline, G., Onana, J.-M. \& Achoundong, G. (2000) The phytogeography and flora of western Cameroon and the Cross River-Sanaga River interval. In Plant Systematics and Phytogeography for the Understanding of African Biodiversity (eds E. Robbrecht, J. Degreef \& I. Friis). Proceedings of the XVIth AETFAT Congress, National Botanic Garden of Belgium, Brussels, Belgium. 
Dickinson, B. (1995) A Reconnaissance Survey of Elephant Populations in the Oban Division of Cross River National Park, Nigeria. Unpublished Report, Kumasi, Ashanti Region, Ghana.

Dunn, A. \& Okon, D. (2003) Monitoring the Abundance of Diurnal Primates and Duikers in Korup National Park, Cameroon. Unpublished Report, Korup Project, Mundemba, Cameroon.

Dupain, J., Guislain, P., Nguenang, G.M., De Vleeschouwer, K. \& Van Elsacker, L. (2004) High chimpanzee and gorilla densities in a non-protected area on the northern periphery of the Dja Faunal Reserve, Cameroon. Oryx, 38, 209-216.

Edderai, D. \& Dame, M. (2006) A census of the commercial bushmeat market in Yaounde, Cameroon. Oryx, 40, 472-475.

Ekobo, A. (2003) Survey of Large Mammals in the Mount Cameroon Forest. Unpublished Report, GTZ Mount Cameroon Project, Buea, Cameroon.

Fraser, P.J., Hall, J.B. \& Healey, J.R. (1998) Climate of the Mount Cameroon Region: Long and Medium Term Rainfall, Temperature and Sunshine Data. School of Agricultural and Forest Sciences Publication No. 16. University of Wales, Bangor, UK.

Gadsby, E.L. \& Jenkins, P.D. (1992) Report on Wildlife and Hunting in the Proposed Etinde Forest Reserve. Unpublished Report, Limbe Botanic Garden and Rainforest Genetic Conservation Project, Limbe, Cameroon.

Gartlan, S. (1989) La Conservation des Ecosystemes Forestiers du Cameroon. Unpublished Report, IUCN Programme pour les Forets Tropicales, IUCN, Gland, Switzerland.

Groves, J.L. (2002) Report on the Status and Distribution of the Cross River gorilla (Gorilla gorilla diehli) Population of the Takamanda and Mone River Forest Reserves and the Mbulu Forest, SW Province. Unpublished Report, WCS-Africa Programme, Limbe, Cameroon, The Whitley Foundation, London, UK and The Margot Marsh Biodiversity Foundation, New York, USA. IUCN (2006) 2006 IUCN Red List of Threatened Species. IUCN, Gland, Switzerland [http://www.redlist.org, accessed 15 December 2006].

Kingdon, J. (1997) The Kingdon Field Guide to African Mammals. Academic Press, London, UK.

Letouzey, R. (1968) Note phytogéographique du Cameroon. Encyclopédie Biologique, 49, 508.

Myers, N., Mittermeier, R.A., Mittermeier, C.G., da Fonseca, G.A.B. \& Kent, J. (2000) Biodiversity hotspots for conservation priorities. Nature, 403, 853-858.

MINEF (Ministry of Environment and Forest) (2001) Gestion Durable des Forets Camerounaises: Plan de Zonage Phase V (Activite 502). MINEF, Yaoundé, Cameroon.

Nchanji, A.C. (2003) Large Mammal Populations and Human Impact Assessment in the Banyang-Mbo Wildlife Sanctuary. Unpublished Report, Wildlife Conservation SocietyBanyand-Mbo Wildlife Sanctuary Project, Nguti, Cameroon. Ntube, E.E.G., Ondoa, T., Mba, A., Fawoh, J., Mojoko, S., Tekwe, C. \& Acworth, J. (2002) Forest Management Plan for the Mokoko River Forest Reserve. Mt Cameroon Project/MINEF, Buea, Cameroon.
Oates, J.F., Bergl, R.A. \& Linder, J.M. (2004) Africa's Gulf of Guinea Forests: Biodiversity Patterns and Conservation Priorities. Advances in Applied Biodiversity Science, No. 6, Centre for Applied Biodiversity Science, Washington, DC, USA.

Sanderson, I.T. (1940) The mammals of the north Cameroons forest area. Transactions of the Zoological Society of London, 24, 623-725.

Struhsaker, T.T. (1967) Preliminary Report on a Survey of High Forest Primates in West Cameroon. Unpublished Report, Rockefeller University \& New York Zoological Society, New York.

Sunderland-Groves, J. \& Maisels, F. (2003) Large mammals of Takamanda Forest Reserve, Cameroon. In Takamanda: The Biodiversity of an African Rainforest (eds J.A. Comiskey, T.C.H. Sunderland \& J.L. Sunderland), pp. 111-127. SI/MAB Series 8, Smithsonian Institution, Washington, DC, USA.

Usongo, L. (1996) Ethnozoological Inventory of the Ejagham Forest Reserve, South West Province. Unpublished Report, CEU Korup Project, Mundemba, Cameroon.

Usongo, L. (1997) Zoological Inventory of Korup National Park Cameroon. Unpublished Report, CEU Korup Project, Mundemba, Cameroon.

Waltert, M., Lien, K.F. \& Muhlenberg, M. (2002) Further declines of threatened primates in the Korup Project Area, south-west Cameroon. Oryx, 36, 257-265.

White, L. \& Edwards, A. (eds) (2000) Conservation Research in the African Rain Forests: A Technical Handbook. Wildlife Conservation Society, New York, USA.

\section{Biographical sketches}

Philip Forboseh is a forest scientist with research interests in land use planning, monitoring and evaluation. For 8 years he worked on conservation and development projects in Cameroon, and now works for Plan Cameroon.

M. Eno-Nku has a particular interest in the ecology and population dynamics of the large mammal fauna of Africa. He is currently concentrating on large mammal surveys and forest elephant radio-collaring in the proposed Mount Cameroon National Park with the WWF Coastal Forest Programme in Cameroon.

Terry Sunderland worked in Cameroon for 14 years on a wide range of conservation and research projects. He was previously the Project Director of the Wildlife Conservation Society Cameroon-Nigeria Transboundary Project. He is now based in Indonesia working for the Centre for International Forestry Research where he focuses on conservation and development issues in Africa and Asia. 